\title{
Ownership Concentration, Managerial Ownership and Firm Performance: Evidence from Turkey
}

Pınar Evrim Mandacı, Guluzar Kurt Gumus*

\section{Abstract:}

This study examines the effects of ownership concentration and managerial ownership on the profitability and the value of non-financial firms listed on the Istanbul Stock Exchange (ISE) in the context of an emerging market. We measure the firm's performance by Return on Assets (ROA) and Tobin's $Q$ ratios, where the former measures profitability and the latter the value of the firm. In addition, we give detailed information on the main characteristics of the ownership structures of the firms in our sample and find that ownership of Turkish firms is highly concentrated. In addition, the unlisted holding companies have the highest average percentage of shares, which supports the belief that individuals or families establish the holding companies in order to control their listed firms. After controlling for investment intensity, leverage, growth and size, we find that ownership concentration has a significantly positive effect on both firm value and profitability, while managerial ownership has a significantly negative effect on firm value.

Keywords: Corporate governance, ownership concentration, managerial ownership, firm performance, Turkey

JEL: G34; G15

DOI: $10.2478 / v 10033-010-0005-4$

\section{Introduction}

Good corporate governance depends on the combination of the protection of the rights of investors and proper ownership concentration. It has been observed that ownership concentration is high in less developed countries, where the rights of investors are not protected due to the outright lack of or insufficient regulation provided by the relevant laws (see Shleifer and Vishny, 1997 and La Porta et al., 1999). The relationship between ownership structure and firm performance provides an idea about the effectiveness of alternative corporate governance mechanisms.

Grossman and Hart (1986) argued that when the ownership structure of a firm is overly diffused, shareholders are not motivated to monitor management decisions closely, because the benefits that they can attain are mostly lower than the cost they would have to afford to control the managers. Yet, this setting may influence performance negatively. On the other side, Shleifer and Vishny (1986) argued that when the ownership structure is concentrated, shareholders will control the activities of the managers easily, thereby avoiding inefficiency in management, and improving firm performance. However, according to the agency theory, Jenson and Meckling (1976) argued that high concentration may simultaneously lead major shareholders to give priority to their own interests, and

\footnotetext{
* Pinar Evrim Mandacı

Dokuz Eylul University, Faculty of Business, Department of Accounting and Finance e-mail: pinar.evrim@deu.edu.tr

\section{Guluzar Kurt Gumus}

Dokuz Eylul University, Faculty of Business, Department of Accounting and Finance e-mail: guluzar.kurt@deu.edu.tr
} 
subsequently agency problems ${ }^{1}$ may occur between the shareholders and managers. In order to minimize agency problems, shareholders have to endure agency costs ${ }^{2}$. In addition, according to them, managerial ownership prevents conflicts of interest between the managers and owners and increases the value of the firm. Significant managerial ownership can align managers' interests with those of the outside shareholders so that managers can have strong incentive to pursue value-maximizing behavior (alignment effects). In contrast, Demsetz (1983) argued that too large an ownership stake by managers could potentially lead them to worry more about their own interests, not those of outside shareholders, hence decreasing the firm's value (entrenchment effects).

In this paper we aim to measure the effects of managerial ownership and ownership concentration on the profitability and value of Turkish non-financial firms listed on the Istanbul Stock Exchange (ISE). In Turkey, the listed corporations are mostly owned by families. Standards of corporate governance and investor protection are lower in Turkey than in the U.S. and other major countries. Hence, we hope that this study will add an interesting dimension to the relation between these variables and performance in a developing country under a poor governance system.

Our paper is organized as follows. The second part consists of a literature review. In the third part, data and summary statistics are presented. Methodology and empirical results are presented in the fourth part, and the final part offers concluding comments.

\section{Literature Review}

Although initially Berle and Means (1932) suggested a positive correlation between ownership concentration and performance, some of the following studies did not observe a relation between these two variables (see Demsetz, 1983; Demsetz and Lehn, 1985 and etc). The study by Demsetz and Lehn (1985) that examined the relationship between accounting profit rate and percentage of shares owned by the five and ten largest shareholders where ownership structure is treated as an endogenous variable found no evidence of a relation between these variables for U.S. companies. They argued that although greater ownership concentration results in

\footnotetext{
${ }^{1}$ It is likely that managers may place personal goals ahead of corporate goals (Gitman, 2006: 20).

${ }^{2}$ The costs borne by stockholders to maintain a governance structure that minimizes agency problems and contributes to the maximization of owner wealth (Gitman, 2006: 20).
}

stronger incentives to monitor, the expected gain from active monitoring and the cost of alternative ownership structures vary across firms. Morck et al. (1988) ignored the endogenous issue and similar to Demsetz and Lehn (1985) found no significant relation in the linear regressions they calculated by using accounting profits and Tobin's $\mathrm{Q}$ as an alternative measure of performance. Shleifer and Vishny (1997) argued that making the ownership structure relatively centralized could promote the shareholder's controlling ability and therefore the existence of the big shareholder was favorable to the growth of a company's value. Himmelberg et al. (1999) argued that the empirical findings might be the result of unobservable firm heterogeneity, which might affect both ownership concentration and performance. These unobserved exogenous firm characteristics might induce a spurious relationship between Tobin's $Q$ and ownership concentration. They found no relation between these two variables after estimating firm fixed effects. Loderer and Martin (1997) and Demsetz and Villalonga (2001) found no influence of ownership concentration on performance for U.S. firms. Their finding is consistent with the view that while exacerbating some agency problems, diffuse ownership also yields compensating advantages that generally offset such problems. On the other hand, Morck et al. (1988) and Hiraki et al. (2003) for Japanese firms, and Gorton and Schmid (2000) for German companies, found a positive relation between ownership concentration and firm value.

In addition to studies on developed countries, most of the studies for developing countries found a positive relation between ownership concentration and performance. Claesses and Djankov (1999) examined Czech companies and argued that the more concentrated the ownership, the higher the firm's profitability; this finding signified the same positive relation as indicated in studies on Czech firms by Claessens (1997) and Weiss and Nikitin (1998). However, their findings were ambiguous when the type of ownership was taken as the control variable. Similar to their previous study in 1997, Xu and Wang (1999) examined Chinese listed firms and found a positive correlation between the shareholding ratio of the first five and ten big shareholders and performance. Sun et al. (2002) proved that relatively bigger holding companies and other big shareholders which had a certain concentration degree could help improve the performance of Chinese firms. Barberis et al. (1996) also found a positive relation for Russian firms. Joh (2003), who examined Korean firms, found that after controlling 
firm and industry characteristics, firms with low ownership concentration recorded low profitability. Yammeesri et al. (2006) examined Tai non-financial firms, and as the literature proved previously, found a positive association between concentrated ownership and performance. Similarly, Omran et al. (2008), in their studies on a group of Arab countries (Egypt, Jordan, Oman, Tunisia), found that ownership concentration was positively correlated with various performance measures, and that large-size firms were more likely to achieve better performance. However, parallel to the findings of Demsetz and Lehn (1985), and Himmelberg et al. (1999), Chen et al. (2005) found for Hong Kong firms that concentrated ownership was not associated with better operating performance or higher firm valuation. Comparably, Gunasekarage et al. (2007) proved that ownership concentration is negatively related to firm performance in China when market-to-book ratio is used as a performance indicator. Gursoy and Aydogan (2002) examined the impact of ownership concentration and ownership mix on firm performance of Turkish nonfinancial firms between 1992 and 1998 and found that higher concentration led to better market performance but lower accounting performance. They used price-toearnings ratio and stock returns to measure market performance.

There are many studies with contending results on the relationship between managerial ownership and performance. Among them, Jensen and Meckling (1976) stated that when managerial ownership increased, conflict would decrease and performance would increase. In contrast, Fama and Jensen (1983) and Stulz (1988) argued that greater stock ownership by managers increased the power of the internal owners and decreased the power of the external owners in terms of influencing performance. Morck et al. (1988) found a significant non-monotonic relationship between Tobin's $\mathrm{Q}$ and board member ownership. Accordingly, the relation increases between $0 \%$ and $5 \%$, decreases between $5 \%$ and $25 \%$, and increases beyond $25 \%$. Their outcomes were also significant when some control variables such as $R \& D$ and advertising ratios, leverage, size, growth and industry dummies were included in models. However, they were not significant when accounting profit rates were used as an alternative performance measure. Similar to the study of Morck et al. (1988), McConnel and Servaes (1990), Hermalin and Weisbach (1991), Cho (1998) and most recently Florackis et al. (2009) found a positive relation for low levels of ownership and a negative relation for high levels of ownership. Yet, unlike Morck et al. (1988), McConnel and Servaes (1990) found that this relationship was also significant when they used accounting profits instead of Tobin's Q. In contrast to other studies, Florackis et al. (2009) found a negative relationship by using a semiparametric estimation approach. As in Morck et al. (1988), Holderness et al. (1999) found a significant positive relation between firm performance and managerial ownership within the $0 \%$ to $5 \%$ range of managerial shareholdings; but in contrast to Morck et al. (1988), they did not find a statistically significant relation beyond $5 \%$. Demsetz and Lehn (1985), Loderer and Martin (1997), and Himmelberg et al. (1999) as well as Demsetz and Villalonga (2001) did not find a significant relation between managerial ownership and performance. Most of those studies examined the association between insider ownership and performance account for the endogeneity of ownership structure except Morck et al. (1988) and McConnell and Servaes (1990). Demsetz and Villalonga (2001) examined US firms and their evidence supported the belief that ownership structure was endogenous but belied the belief that ownership structure affected firm performance. They argued that if there were compensating advantages in a firm, there would be no systematic relation between managerial shareholdings and firm performance. In addition, they argued that it might indicate that this relationship depends on location, special local laws and governance practices. There is no study which examines the relationship between managerial ownership and the performance of Turkish firms.

As can be seen from the above, the empirical results on the effects of managerial ownership and ownership concentration on firm performance are conflicting. In addition, the previous studies focused mostly on large industrialized countries, which completed their institutionalization process; therefore, their outcomes might not be relevant for developing countries. In this study, we try to fill this gap by examining this issue for a developing country, namely Turkey.

\section{Data and Summary Statistics}

Our sample includes all non-financial firms listed on the ISE in the year 2005. The number of firms in our sample is 203. We excluded banks and leasing, investment, insurance and holding companies since their financial tables are different from non-financial firms. We 
collected data on market values of the sample firms from the Monthly (December) Bulletins of the ISE. We used annual company reports issued by the ISE to obtain data on ownership structure (ownership concentration, managerial ownership, etc.). We obtained the remaining data by using the balance sheets and income statements from the ISE's website.

In line with previous studies (such as Morck et al.,1988; McConnel and Servaes, 1990 and etc.), we also focused on one year of data by taking into consideration the fact that the ownership structure of the firm does not vary frequently. In addition, the International Financial Reporting Standards have been applied in Turkey since the beginning of 2005 . The firms are required to incorporate the new standards and to prepare more detailed annual reports which provide more data to finance researchers and consequently facilitate the analysis of firms' ownership structures. Hence, this study takes 2005 to be the starting line.

Table 1 depicts the number of the different types of shareholders of the present study's sample firms operating in different industries. According to this table, individuals and families, unlisted holding companies and unlisted non-financial firms pre-dominate the ownership positions in the sample firms. Furthermore, this predominance is mostly seen in the textile industry. Additionally, most of the shareholders are foreign companies in the food industry, listed holding companies in the metal products industry and listed non-financial firms in the stone and soil industry. The ownership positions of the state, foundations and labor unions are very low compared to other parties.

Table 2 denotes the average percentage of shares held by the owners of the sample firms in different industries. The highest average percentage of shares is held by unlisted holding companies, which supports the belief that individuals or families establish the holding companies in order to control their listed firms. It is followed by the unlisted non-financial firms and individuals and families respectively.

Table 3 depicts the proportion of shares held by the Board members and managers as well as their relatives. In Turkey it is often observed that the family members are the CEOs, Boards of Directors or top managers of the firms. As a result, management control is in the hands of these family members (see Yurtoğlu, 1998 and Demirağ and Serter, 2003). Table 3 denotes that CEOs, Boards of directors and top managers have almost $8.38 \%$ of shares outstanding. And their relatives have almost 3\% of the outstanding shares. Board members and general

\begin{tabular}{|c|c|c|c|c|c|c|c|c|c|c|c|}
\hline Industries & $\begin{array}{l}\overline{0} \\
\frac{0}{0} \\
\frac{0}{2} \\
\frac{1}{0} \\
\text { I }\end{array}$ & 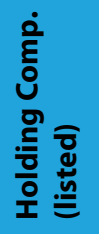 & 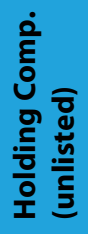 & 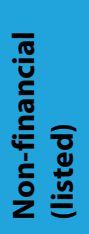 & 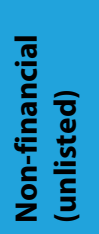 & 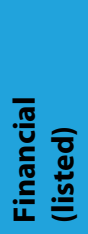 & 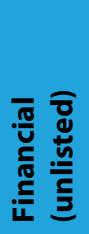 & $\begin{array}{l}\text { 동 } \\
\text { 힌 }\end{array}$ & 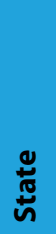 & 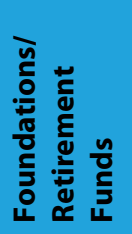 & $\begin{array}{l}\frac{n}{0} \\
\frac{0}{c} \\
\frac{1}{0} \\
\frac{0}{0}\end{array}$ \\
\hline Food & 14 & 3 & 9 & 1 & 10 & - & - & 9 & 1 & 1 & 1 \\
\hline Textile & 31 & 4 & 14 & 4 & 15 & 3 & 1 & 1 & - & - & 1 \\
\hline Wood and Paper & 9 & 4 & 10 & 4 & 7 & - & - & 4 & 1 & 1 & - \\
\hline Chemical & 7 & 3 & 8 & 1 & 9 & - & - & 5 & 1 & 5 & 1 \\
\hline Stone and Soil & 7 & 6 & 5 & 6 & 10 & 2 & 3 & 6 & 3 & 7 & 1 \\
\hline Metal Main & 7 & 3 & 5 & 1 & 3 & - & 1 & 1 & 2 & 1 & 1 \\
\hline Metal Products & 13 & 9 & 13 & 1 & 10 & - & - & 8 & 1 & 1 & - \\
\hline $\begin{array}{l}\text { Other Manufacturing } \\
\text { Firms }\end{array}$ & 1 & - & 2 & - & - & - & - & 1 & - & - & - \\
\hline Technology & 4 & - & 2 & - & - & - & - & 3 & 1 & 1 & - \\
\hline $\begin{array}{l}\text { Education, Sport and } \\
\text { Health }\end{array}$ & 3 & - & - & - & 4 & - & - & 1 & - & - & 1 \\
\hline Telecommunication & 2 & - & 2 & - & 1 & 1 & 1 & 2 & 1 & - & - \\
\hline Wholesale and Retail & 10 & 5 & 6 & 2 & 8 & - & - & 2 & - & 1 & - \\
\hline $\begin{array}{l}\text { Electricity and } \\
\text { Construction }\end{array}$ & 4 & - & 2 & 2 & 5 & 1 & 1 & 2 & - & 1 & - \\
\hline Total & 112 & 37 & 78 & 22 & 82 & 7 & 7 & 45 & 11 & 19 & 6 \\
\hline
\end{tabular}

Table 1: The Number and Types of Shareholders of Non-financial Firms in Different Industries (Year 2005) 


\begin{tabular}{|c|c|c|c|c|c|c|c|c|c|c|c|c|c|c|c|}
\hline \multirow{2}{*}{ Industry } & \multirow{2}{*}{ 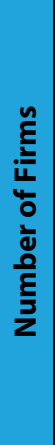 } & \multirow{2}{*}{ 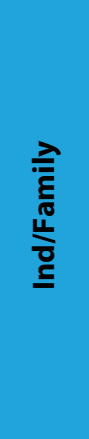 } & \multirow{2}{*}{\multicolumn{3}{|c|}{ Holding }} & \multirow{2}{*}{\multicolumn{3}{|c|}{ Non-financial firm }} & \multirow{2}{*}{\multicolumn{3}{|c|}{ Financial Firm }} & \multirow{2}{*}{$\begin{array}{l}\text { 동 } \\
\text { 는 } \\
\text { 난 }\end{array}$} & \multirow{2}{*}{ ڤัँ } & \multirow{2}{*}{ 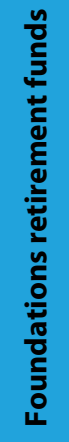 } & \multirow{2}{*}{ 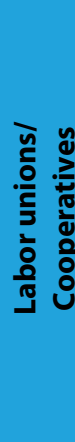 } \\
\hline & & & & & & & & & & & & & & & \\
\hline Food & 24 & 14.56 & 3.81 & 9.40 & 13.21 & 0.38 & 10.25 & 10.64 & 0.00 & 0.00 & 0.00 & 18.35 & 0.99 & 3.22 & 0.01 \\
\hline Textile & 35 & 29.06 & 3.39 & 15.54 & 18.93 & 2.85 & 9.84 & 12.69 & 3.36 & 0.22 & 3.58 & 2.46 & 0.00 & 0.00 & 0.23 \\
\hline Metal Main & 13 & 5.95 & 11.21 & 20.11 & 31.32 & 4.41 & 9.63 & 14.04 & 0.00 & 0.24 & 0.24 & 0.40 & 1.32 & 0.10 & 1.62 \\
\hline Metal Products & 25 & 5.97 & 14.04 & 24.20 & 38.23 & 0.89 & 8.94 & 9.83 & 0.00 & 0.00 & 0.00 & 15.72 & 0.01 & 0.18 & 0.00 \\
\hline $\begin{array}{l}\text { Other Manufacturing } \\
\text { Firms }\end{array}$ & 3 & 9.44 & 0.00 & 31.73 & 31.73 & 0.00 & 0.00 & 0.00 & 0.00 & 0.00 & 0.00 & 5.13 & 0.00 & 0.00 & 0.00 \\
\hline Technology & 8 & 24.77 & 0.00 & 13.66 & 13.66 & 0.00 & 0.00 & 0.00 & 0.00 & 0.00 & 0.00 & 19.21 & 10.57 & 1.88 & 0.00 \\
\hline $\begin{array}{l}\text { Education, Sport and } \\
\text { Health }\end{array}$ & 6 & 15.58 & 0.00 & 0.00 & 0.00 & 0.00 & 54.81 & 54.81 & 0.00 & 0.00 & 0.00 & 2.36 & 0.00 & 0.00 & 0.00 \\
\hline Telecommunication & 4 & 7.73 & 0.00 & 28.77 & 28.77 & 0.00 & 0.00 & 0.00 & 0.00 & 0.02 & 0.02 & 19.54 & 18.80 & 0.00 & 0.00 \\
\hline Wholesale and Retail & 15 & 16.63 & 7.68 & 12.32 & 20.00 & 4.74 & 12.07 & 16.81 & 0.00 & 0.00 & 0.00 & 9.30 & 0.00 & 0.00 & 0.00 \\
\hline $\begin{array}{l}\text { Electricity and } \\
\text { Construction }\end{array}$ & 5 & 10.78 & 0.00 & 14.25 & 14.25 & 6.76 & 27.64 & 34.40 & 5.08 & 0.22 & 5.30 & 2.27 & 0.00 & 1.24 & 0.00 \\
\hline
\end{tabular}

Table 2: Ownership Structure of Non- financial Firms in Different Industries (in \%, Year 2005)

managers have a considerable share in the technology industry (24.05 percent). The average of openness-to-public is 33 percent within sample firms.

Table 4 gives the percentage of shares owned by the largest three, five and ten shareholders for the sample firms in different industries. It shows that the largest shareholder has around 48 percent of shares, which indicates that one person or an institution has almost half of a listed company. The averages for the largest three, five and ten are 61.27; 64.20 and 65.93 respectively. Moreover, the highest ownership concentration is in education, sport and health industry for the largest shareholder and in the telecommunication industry for the largest three, five and ten shareholders.

\begin{tabular}{|l|c|c|c|}
\hline Industry & $\begin{array}{c}\text { Share of Board } \\
\text { Members and } \\
\text { General } \\
\text { Manager }\end{array}$ & $\begin{array}{c}\text { Share of } \\
\text { Family } \\
\text { Members }\end{array}$ & $\begin{array}{c}\text { Open-to- } \\
\text { Public (\%) }\end{array}$ \\
\hline Food & 9.70 & 1.70 & 38.16 \\
\hline Textile & 15.87 & 7.76 & 33.35 \\
\hline Wood and Paper & 4.54 & 3.16 & 29.65 \\
\hline Chemical & 2.79 & 0.92 & 31.89 \\
\hline Stone and Soil & 4.87 & 2.36 & 30.11 \\
\hline Metal Main & 2.06 & 2.95 & 44.78 \\
\hline Metal Products & 4.22 & 0.56 & 30.77 \\
\hline Other Manufacturing Firms & 9.44 & 0 & 53.69 \\
\hline Technology & 24.06 & 0.40 & 30.06 \\
\hline Education, Sport and Health & 12.71 & 1.80 & 27.25 \\
\hline Telecommunication & 7.73 & 0 & 25.15 \\
\hline Wholesale and Retail & 11.35 & 3.38 & 37.21 \\
\hline Electricity and Construction & 4.63 & 0.19 & 31.77 \\
\hline Average & $\mathbf{8 . 3 8}$ & $\mathbf{3 . 0 5}$ & $\mathbf{3 3 . 4 8}$ \\
\hline
\end{tabular}

Table 3: Managerial Ownership in Non-financial firms (in \%, Year 2005) 


\begin{tabular}{|c|c|c|c|c|}
\hline \multirow[b]{2}{*}{ Industry } & \multicolumn{4}{|c|}{ Ownership Concentration } \\
\hline & Top 1 Shareholder & Top 3 Shareholders & Top 5 Shareholders & $\begin{array}{c}\text { Top } 10 \\
\text { Shareholders }\end{array}$ \\
\hline Food & 40.48 & 56.75 & 58.57 & 59.77 \\
\hline Textile & 38.00 & 54.76 & 60.25 & 65.74 \\
\hline Wood and Paper & 49.20 & 65.19 & 67.96 & 69.87 \\
\hline Chemical & 52.98 & 66.37 & 68.05 & 68.28 \\
\hline Stone and Soil & 53.06 & 65.39 & 68.69 & 69.56 \\
\hline Metal Main & 47.33 & 53.10 & 54.10 & 55.03 \\
\hline Metal Products & 52.87 & 66.32 & 67.88 & 68.62 \\
\hline Other Manufacturing Firms & 38.04 & 46.31 & 46.31 & 46.31 \\
\hline Technology & 54.28 & 68.17 & 70.08 & 70.08 \\
\hline Education, Sport and Health & 63.43 & 69.16 & 72.43 & 72.90 \\
\hline Telecommunication & 59.01 & 69.35 & 74.39 & 80.63 \\
\hline Wholesale and Retail & 42.12 & 60.46 & 62.20 & 62.47 \\
\hline Electricity and Construction & 36.43 & 55.23 & 63.75 & 67.83 \\
\hline Average & 48.25 & 61.27 & 64.20 & 65.93 \\
\hline
\end{tabular}

Table 4: The Ownership Concentration Rates for Non-financial Firms (in \%, Year 2005)

We used two measures of performance as dependent variables, Return on Assets (ROA) and Tobin's $Q$ ratios, where the former measures profitability and the latter the value of the firm. We used two independent variables, the percentage of shares held by the largest three shareholders and the percentage of shares held by the managers. We observed that the studies on Turkish firms (such as Gursoy and Aydogan, 2002 and Demirağ and Serter, 2003) prefer using the share of the largest three shareholders to measure ownership concentration. Depending on these previous studies as well as our outcomes about the concentration rates presented in
Table 4, we used the percentage of shares held by the largest three shareholders to measure ownership concentration. Our control variables are the investment intensity, leverage, growth and size which are assumed to have an effect on firm performance. In addition to these we employ industry dummy variables in order to point out whether the performance measures differ across industries. The study's variables and their definitions are presented in Table 5.

\begin{tabular}{|l|l|}
\hline Dependent Variables & Definition \\
\hline TOBIN'S Q & Market value of assets (total debt plus market value of equity)/total assets \\
\hline ROA & Net Income/Total Assets \\
\hline Independent Variables & Total share of the largest three shareholders in the firm \\
\hline CON3 & Managerial Ownership: Percentage of Shares Owned by the managers \\
\hline OWNER & Capital Expenditures/Sales (investment intensity) \\
\hline Control Variables & Total Debt/Total Equity (Leverage) \\
\hline CAPEXP & Average growth in net sales over three-year period (2003-2005) \\
\hline DEBTTA & Logarithm of total assets \\
\hline GROWTH & $\begin{array}{l}\text { Education-health; electricity; food-beverage; chemical-petroleum-plastic; metal products- } \\
\text { machinery; wood-paper-printing; non-metal mineral products; technology; textile- } \\
\text { leather; wholesale and retail trade; transportation. }\end{array}$ \\
\hline SIZE &
\end{tabular}

Table 5: Variables and Definitions 


\begin{tabular}{|l|c|c|c|c|c|}
\hline & ROA & TOBIN'S Q & CAPEXP & DEBTTA & GROWTH \\
\hline Mean & 0.054 & 1.435 & 0.084 & 0.245 & 0.117 \\
\hline Maximum & 0.592 & 5.842 & 3.602 & 0.775 & 2.451 \\
\hline Minimum & -0.388 & 0.360 & -8.408 & 0.0001 & -0.620 \\
\hline Std. Dev. & 0.118 & 0.791 & 0.816 & 0.179 & 0.353 \\
\hline
\end{tabular}

Table 6: Descriptive Statistics

\begin{tabular}{|c|c|c|c|c|c|c|c|}
\hline & ROA & CON3 & OWNER & CAPEXP & DEBTTA & GROWTH & SIZE \\
\hline ROA & 1 & & & & & & \\
\hline CON3 & 0.223 & 1 & & & & & \\
\hline OWNER & 0.083 & -0.222 & 1 & & & & \\
\hline CAPEXP & 0.081 & -0.077 & -0.048 & 1 & & & \\
\hline DEBTTA & -0.277 & -0.1624 & 0.094 & 0.030 & 1 & & \\
\hline GROWTH & 0.281 & 0.005 & -0.095 & 0.108 & -0.043 & 1 & \\
\hline SIZE & 0.177 & 0.119 & -0.163 & -0.038 & 0.133 & 0.035 & 1 \\
\hline
\end{tabular}

$* * *, * * *$ indicate $1 \%, 5 \%$ and $10 \%$ significance.

Table 7A. Correlation Matrix (between ROA and independent variables)

\begin{tabular}{|c|c|c|c|c|c|c|c|}
\hline & TOBINSQ & CON3 & OWNER & CAPEXP & DEBTTA & GROWTH & SIZE \\
\hline TOBINSQ & 1 & & & & & & \\
\hline CON3 & 0.161 & 1 & & & & & \\
\hline OWNER & -0.085 & -0.212 & 1 & & & \\
\hline CAPEXP & 0.108 & -0.076 & -0.050 & 1 & & & \\
\hline DEBTTA & -0.364 & -0.142 & 0.059 & 0.028 & 1 & & \\
\hline GROWTH & 0.180 & 0.003 & -0.089 & 0.108 & -0.028 & 1 & \\
\hline SIZE & -0.126 & 0.215 & -0.302 & -0.055 & -0.046 & 0.083 & 1 \\
\hline
\end{tabular}

$* * *, * *, *$ indicate $1 \%, 5 \%$ and $10 \%$ significance.

Table 7B. Correlation Matrix (between Tobins $Q$ and independent variables)

The descriptive statistics for variables are presented in Table 6. For the year 2005, the average ROA was 0.05 while the highest ROA was 0.59. Mean of Debt-to-Total Assets indicates that Turkish companies prefer financing their companies with capital instead of debt. The highest standard deviation belongs to capital expenditures and Tobin's $Q$, showing the highest variance among companies.

Tables $7 \mathrm{~A}$ and $\mathrm{B}$ show the correlation matrix for each dependent variable. The correlation coefficients among independent variables are low. Additionally, correlation coefficients between independent and dependent variables are consistent with the direction of the relation and coefficients found in the regressions analysis.

\section{Methodology and Empirical Results}

We applied multiple regression analysis to measure the effects of ownership concentration and managerial ownership on firm performance. We developed two different groups of hypotheses on the relationship of ownership concentration and managerial ownership with firm performance. In parallel to most of the previous studies on developing countries, we expected a positive relationship between ownership concentration and firm performance. Since the ownership concentration is high in Turkey, the shareholder can easily control the managers and force them to focus on the maximization of the shareholders' wealth. Agency theory suggests that when the managerial ownership increases, the conflict of interest between the managers and owners will decrease and firm performance will increase. Although most of the previous studies did not observe a relation between managerial ownership and firm performance, in line with the theory, we expected a positive relationship between them. The hypotheses of the study are stated below;

$\mathrm{H} 1_{0}$. The ownership concentration is not significantly related to firm performance.

$\mathrm{H} 1_{1}$. The ownership concentration is positively correlated to firm performance. 
$\mathrm{H} 2_{0}$. The level of managerial ownership is not significantly related to firm performance.

$\mathrm{H} 2_{1}$. The level of managerial ownership is positively correlated to firm performance.

Different models were constructed to explore the effects of the independent variables. In models where the ROA and TOBINSQ are the dependent variables, first all variables other than industry dummies were included in the analysis, and then the industry dummies were included to investigate the industry effects on firm value and profitability. The four models of the study are presented below. of education, food and beverage and wholesale industries on firm performance. After we included the industry dummies, the adjusted $R^{2}$ increased to 0.34 from 0.18 .

The positive relationship between ownership concentration and performance supports the study of Shleifer and Vishny (1997) who state that since investor protection is low in developing countries, ownership concentration is accepted as an alternative corporate governance tool in these countries. Our findings are also parallel to previous studies on developing countries such as Barberis et al. (1996), Claesses and Djankov (1999), Joh (2002), Yammeesri et al. (2006). However, our result on

Model 1:

$R O A_{i}=\beta_{0}+\beta_{1} \mathrm{CON}_{i}+\beta_{2} O W N E R_{i}+\beta_{4} C A P E X P_{i}+\beta_{5}$ DEBTTA $_{i}+\beta_{6}$ GROWTH $_{i}+\beta_{7}$ SIZE $_{i}+\varepsilon_{i}$

Model 2:

$R O A_{i}=\beta_{0}+\beta_{1} \mathrm{CON}_{i}+\beta_{2} O W N E R_{i}+\beta_{4} \mathrm{CAPEXP}_{i}+\beta_{5} \mathrm{DEBTTA}_{i}+\beta_{6} \mathrm{GROWTH}_{i}+\beta_{7} \mathrm{SIZE}_{i}+D_{i}+\varepsilon_{i}$

Model 3:

TOBINSQ $_{i}=\beta_{0}+\beta_{1}$ CON3 $_{i}+\beta_{2}$ OWNER $_{i}+\beta_{4}$ CAPEXP $_{i}+\beta_{5}$ DEBTTA $_{i}+\beta_{6}$ GROWTH $_{i}+\beta_{7}$ SIZE $_{i}+\varepsilon_{i}$

Model 4:

TOBINSQ $_{i}=\beta_{0}+\beta_{1}$ CON3 $_{i}+\beta_{2}$ OWNER $_{i}+\beta_{4}$ CAPEXP $_{i}+\beta_{5}$ DEBTTA $_{i}+\beta_{6}$ GROWTH $_{i}+\beta_{7}$ SIZE $_{i}+D_{i}+\varepsilon_{i}$

Table 7 presents the regression results for ROA and Tobin's Q. In Models 1 and 2, we used ROA as a measure of profitability and found a significant positive effect among the largest three shareholders on firm profitability in the models in which the dummies were excluded. Debt-to-total assets and growth variables also had significant effects in all models. Additionally, the dummy for the education industry has a significant effect, but managerial ownership and capital expenditures did not have an effect on profitability. When we added the dummy variables in the model, the adjusted $R^{2}$ increased to 0.276 from 0.182 .

In Models 3 and 4, we used Tobin's $Q$ as an indicator of firm value and found that the largest three shareholders had a significant positive effect, and that managerial ownership had a significant negative effect on firm value. When we included the dummy variables, we did not find a significant relationship between managerial ownership and firm value. In addition, Debt-to-total assets and size variables were the other factors that affected firm value negatively. Capital expenditure and growth did not have a significant effect on firm value. The model with dummy variables of industries pointed out the significant effects the relationship between the ownership concentration and profitability is the opposite of that of Gursoy and Aydogan (2002) which found a negative relationship between ownership concentration and profitability. The findings on the effects of managerial ownership are much more conflicted in the literature. Our finding does not support the agency theory. The negative relation between managerial ownership and firm value might be explained by Demsetz (1983), who argued that too much managerial ownership could potentially lead managers to worry more about their own interests, and not those of outside shareholders, hence decreasing firm value.

\section{Concluding Comments}

The empirical results on the effects of managerial ownership and ownership concentration on firm performance are conflicting. Previous studies focused mostly on large industrialized countries, which completed their institutionalization process and therefore, their outcomes might not be relevant for developing countries. In this study, we try to fill this gap by examining the effects of ownership concentration and managerial 


\begin{tabular}{|c|c|c|c|c|}
\hline \multirow{2}{*}{ Regressor } & \multicolumn{2}{|c|}{ ROA } & \multicolumn{2}{|c|}{ TOBINSQ } \\
\hline & Model 1 & Model 2 & Model 3 & Model 4 \\
\hline \multirow{2}{*}{ CON3 } & 0.001 & 0.001 & 0.006 & 0.007 \\
\hline & $1.976^{* *}$ & $(1.546)$ & $1.656^{*}$ & $\left.(2.056)^{* *}\right)$ \\
\hline \multirow{2}{*}{ OWNER } & 0.0002 & -0.0002 & -0.003 & -0.007 \\
\hline & 0.469 & $(-0.464)$ & -0.844 & $(-2.091)^{* *}$ \\
\hline \multirow{2}{*}{ CAPEXP } & 0.011 & 0.011 & 0.082 & 0.067 \\
\hline & 1.006 & $(1.053)$ & 1.126 & (1.019) \\
\hline \multirow{2}{*}{ DEBTTA } & -0.169 & -0.121 & -1.504 & -1.003 \\
\hline & $-3.194^{* * *}$ & $(-1.986)^{* *}$ & $-4.074^{* * *}$ & $(-2.535)^{* *}$ \\
\hline \multirow{2}{*}{ GROWTH } & 0.080 & 0.067 & 0.352 & 0.285 \\
\hline & $3.086^{* * *}$ & $(2.471)^{* *}$ & $1.991^{* *}$ & (1.613) \\
\hline \multirow{2}{*}{ SIZE } & 0.037 & 0.034 & -0.320 & -0.400 \\
\hline & $2.284^{* *}$ & $(1.930)^{*}$ & $-2.288^{* *}$ & $(-2.833)^{* * * *}$ \\
\hline Education-Health & & $\begin{array}{r}0.158 \\
(2.304)^{* * *}\end{array}$ & & $\begin{array}{r}2.214 \\
(4.977)^{* * *}\end{array}$ \\
\hline Electricity & & $\begin{array}{r}-0.089 \\
(-1.528)\end{array}$ & & $\begin{array}{r}0.208 \\
(0.544)\end{array}$ \\
\hline Food-Beverage & & $\begin{array}{r}-0.004 \\
(-0.089)\end{array}$ & & $\begin{array}{r}0.617 \\
(2.099)^{* *}\end{array}$ \\
\hline Chemical-Petroleum-Plastics & & $\begin{array}{r}0.026 \\
(0.527)\end{array}$ & & $\begin{array}{r}0.319 \\
(1.005)\end{array}$ \\
\hline Metal Products-Machinery & & $\begin{array}{r}0.004 \\
(0.106)\end{array}$ & & $\begin{array}{r}0.059 \\
(0.205)\end{array}$ \\
\hline Wood-Paper-Printing & & $\begin{array}{r}-0.037 \\
(-0.824)\end{array}$ & & $\begin{array}{r}0.103 \\
(0.351)\end{array}$ \\
\hline Non-Metal Products & & $\begin{array}{r}0.044 \\
(0.973)\end{array}$ & & $\begin{array}{r}0.475 \\
(1.609)\end{array}$ \\
\hline Technology & & $\begin{array}{r}0.093 \\
(1.286)\end{array}$ & & $\begin{array}{r}0.543 \\
(1.158)\end{array}$ \\
\hline Textile-Leather & & $\begin{array}{r}-0.037 \\
(-0.937)\end{array}$ & & $\begin{array}{r}0.119 \\
(0.463)\end{array}$ \\
\hline Wholesale And Retail Trade & & $\begin{array}{r}0.012 \\
(0.257)\end{array}$ & & $\begin{array}{r}0.541 \\
(1.731)^{*}\end{array}$ \\
\hline Transportation & & $\begin{array}{r}0.111 \\
(1.411)\end{array}$ & & $\begin{array}{r}0.541 \\
(0.799)\end{array}$ \\
\hline C & $\begin{array}{r}-0.281 \\
-2.145^{* *}\end{array}$ & $\begin{array}{r}-0.248 \\
(-1.770)^{*}\end{array}$ & $\begin{array}{r}4.043 \\
3.522^{* * * *}\end{array}$ & $\begin{array}{r}4.257 \\
(3.742)^{* * *}\end{array}$ \\
\hline Adjusted R2 & 0.182 & 0.276 & 0.180 & 0.341 \\
\hline
\end{tabular}

***, ${ }^{* *}, *$ indicate $1 \%, 5 \%$ and $10 \%$ significance.

Table 7: Regression Results

ownership on the performance of Turkish firms listed on the ISE in the context of a developing country. We measured firm performance by ROA (Return on Assets) and Tobin's $Q$, where the former measures profitability and the latter firm value. We tried to test the relationships between these performance measures and the percentage of shares owned by the largest three shareholders, and the percentage of shares held by board members and general managers. In addition to these independent variables, we used control variables including investment intensity, leverage, growth and size and industry dummies, which are assumed to have an effect on firm performance.

In addition, we analyzed the ownership structure of the sample firms and found that the highest average percentage of shares was held by the unlisted holding companies, unlisted non-financial firms and individuals and families, respectively, which confirms the widespread belief that in Turkey individuals or families set up their unlisted firms in order to control their listed companies. Supporting the studies of Gursoy and Aydogan (2002) and Gönenç (2004), we found that the ownership of Turkish firms is highly concentrated. Our regression results show that ownership concentration has a significant positive effect on both firm value and profitability. This result may support the idea of Schleifer and Vishny (1997) who state that since investor protection is low in developing countries, ownership concentration is accepted as an alternative corporate governance mechanism in these countries. On the other hand, in contrast to the agency theory, we found a negative relation between managerial ownership and firm value, which might support the argument of Demsetz, who states that too much managerial ownership could potentially lead managers to worry more about their own interests and decrease firm value. The finding does not support the idea of Jensen and Meckling (1976), who argue that as managerial ownership increases, the conflict between the managers and owners will decrease and performance will increase. The results of the study suggest that Turkish firms can increase their performance by increasing their ownership concentration and by decreasing managerial ownership. 
We believe, despite the uniqueness of the results, that this study proves that the subject deserves greater attention and more detailed analysis. We did not add other agency variables such as the number of independent directors, board composition, etc., since the full data is not available in annual reports. Future studies might collect this data by directly contacting the firms. In addition, future studies might include financial firms and holding companies. ㄷ.

\section{References}

Barberis, N., M. Boycko, A. Shleifer, N. Tsukanova (1996). "How does privatization work? Evidence from the Russian shops". Journal of Political Economy, 104, $764-790$.

Berle, A., G. Means (1932). The Modern Corporation and Private Property. Harcourt, Brace, \&World, New York.

Chen, Z., Y.-L. Cheung, A. Strouraitis, A.W.S. Wang (2005). "Ownership concentration, firm performance, and dividend policy in Hong Kong". Pacific-Basin Finance Journal, 13, 431- 449.

Cho, M-H. (1998). "Ownership structure, investment, and the corporate value: An empirical

Analysis". Journal of Financial Economics, 47, 103-121.

Claessens, S. (1997). "Corporate governance and equity prices: Evidence from the Czech and Slovak Republics". Journal of Finance, 52, 1641-1658.

Claesses, S., S. Djankov (1999). "Ownership concentration and corporate performance

in the Czech Republic". Journal of Comparative Economics, 27, 498513

Demirağ, I., M. Serter (2003). "Ownership Patterns and Control in Turkish Listed Companies". Corporate Governance: An International Review, 11, 40-51.

Demsetz, H. (1983). "The structure of ownership and the theory of the firm". Journal of Law and Economics, 26, 375-390.

Demsetz, H., K. Lehn (1985). "The structure of corporate ownership: Causes and consequences". Journal of Political Economy, 93, 1155-1177.

Demsetz, H., B. Villalonga (2001). "Ownership structure and corporate performance". Working paper. UCLA.

Fama E., M. Jensen (1983). "Separation of ownership and control". Journal of Law and Economics, 26, 301-325.

Florackis, C., A. Kostakis, A. Ozkan (2009). "Managerial ownership and performance". Journal of Business Research, 62, 1350-1357.

Gitman, L. (2006). Principles of Managerial Finance. Addison Wesley Longman.

Gorton, G., F.A. Schmid (2000). "Universal banking and the performance of German firms". Journal of Financial Economics, 58, 29-80.

Gönenç, H. (2004). VIII. National Finance Symposium, 27-28 October, Istanbul Technical University. Istanbul, 157-167.

Grossman, S., O. Hart. (1986). "The costs and benefits of ownership: A theory of vertical and lateral integration". Journal of Political Economy, 94, 691-719.

Gunasekarage, A., K. Hess, A. Hu (2007). "The influence of the degree of state ownership and the ownership concentration on the performance of listed Chinese companies". Research in International Business and Finance, 21, 379-395.

Gursoy, G., K. Aydogan (2002). "Equity ownership structure, risk taking and performance". Emerging Markets Finance and Trade, 38, 6-25.

Hermalin, B. E., M. S. Weibach (1991). "The effect of board composition and direct incentives on firm performance". Financial Management, 21, 101- 112 .

Himmelberg, C., R.G. Hubbard, D. Palia (1999). "Understanding the determinants of managerial ownership and the link between ownership and performance". Journal of Financial Economics, 53, 353-384.
Hiraki, T., H. Inoue, A. Ito, F. Kuroki, H. Masuda (2003). "Corporate governance and firm value in Japan: Evidence from 1985 to 1998 ". Pacific-Basin Finance Journal, 11, 239-265.

Holderness, C., R. Kroszner, D. Sheehan (1999). "Were the good old days that good? Evolution of managerial stock ownership and corporate governance since the Great Depression". Journal of Finance, 54, 435-469.

Jensen, M., W. Meckling (1976). "Theory of the firm: managerial behavior, agency costs, and ownership structure". Journal of Financial Economics, 3, 305-360.

Joh, S.W. (2003). "Corporate governance and firm profitability: Evidence from Korea before the, economic crisis". Journal of Financial Economics, 68, 287-322.

La Porta, R., F.Lopez-de-slanes, A Shleifer,. R. Vishny (1999). "Corporate ownership around the world". Journal of Finance, 54, 471518.

Loderer, C., and K. Martin (1997). "Executive stock ownership and performance: tracking faint traces". Journal of Financial Economics, 45, 223-255.

McConnell, J., H. Servaes (1990). "Additional evidence on equity ownership and corporate value". Journal of Financial Economics, 27, 595612.

Morck, R., A. Shleifer, R. Vishny (1988). "Management ownership and market valuation: an empirical analysis". Journal of Financial Economics, 20, 293-315.

Omran, M. M., A. Bolbol, A. Fatheldin (2008). "Corporate governance and firm performance in Arab equity markets: does ownership concentration matter?" International Review of Law and Economics, 28, $32-45$.

Shleifer, A., R. Vishny. (1986). "Large shareholders and corporate control". Journal of Political Economy, 94, 431-488.

Shleifer, A., R. Vishny (1997). "A survey of corporate governance". Journal of Finance, 52, 737-783.

Stulz, R.M. (1988). "Managerial control of voting rights: Financing policies and the market for corporate control". Journal of Financial Economics, 20, 25-54.

Sun, Q., W. Tong, J. Tong (2002). "How does government ownership affect firm performance? Evidence from China's privatization experience". Journal of Business Finance and Accounting, 29, 1-27.

Weiss, A., and G. Nikitin (1998). "Performance of Czech companies by ownership structure". University of Michigan: William Davidson Institute, The Davidson Institute Working Paper 186.

Xu, X.,Y. Wang (1997). "Ownership structure, corporate governance, and corporate performance: The case of Chinese stock companies". World Bank Working Paper 1794, World Bank.

Xu, X., Y. Wang (1999). "Ownership structure and corporate governance in Chinese stock companies". China Economic Review, 10, 75-98.

Yammeesri, J., S. J. Lodh, S. K. Herath (2006). "Influence of ownership structure and corporate performance pre-crisis: evidence from Thailand". International Journal of Electronic Finance, 1, 181-199.

Yurtoglu, B.B. (1998). "Ownership Structure of Turkish Listed Firms". ISE Finance Award Series 1: 55-84. 